\title{
Cross-reactivity of steroid hormone immunoassays: clinical significance and two-dimensional molecular similarity prediction
}

\author{
Matthew D Krasowski ${ }^{*}$, Denny Drees ${ }^{1}$, Cory S Morris ${ }^{1}$, Jon Maakestad ${ }^{1}$, John L Blau ${ }^{1,2}$ and Sean Ekins ${ }^{3}$
}

\begin{abstract}
Background: Immunoassays are widely used in clinical laboratories for measurement of plasma/serum concentrations of steroid hormones such as cortisol and testosterone. Immunoassays can be performed on a variety of standard clinical chemistry analyzers, thus allowing even small clinical laboratories to do analysis on-site. One limitation of steroid hormone immunoassays is interference caused by compounds with structural similarity to the target steroid of the assay. Interfering molecules include structurally related endogenous compounds and their metabolites as well as drugs such as anabolic steroids and synthetic glucocorticoids.
\end{abstract}

Methods: Cross-reactivity of a structurally diverse set of compounds were determined for the Roche Diagnostics Elecsys assays for cortisol, dehydroepiandrosterone (DHEA) sulfate, estradiol, progesterone, and testosterone. These data were compared and contrasted to package insert data and published cross-reactivity studies for other marketed steroid hormone immunoassays. Cross-reactivity was computationally predicted using the technique of two-dimensional molecular similarity.

Results: The Roche Elecsys Cortisol and Testosterone II assays showed a wider range of cross-reactivity than the DHEA sulfate, Estradiol II, and Progesterone II assays. 6-Methylprednisolone and prednisolone showed high cross-reactivity for the cortisol assay, with high likelihood of clinically significant effect for patients administered these drugs. In addition, 21-deoxycortisol likely produces clinically relevant cross-reactivity for cortisol in patients with 21-hydroxylase deficiency, while 11-deoxycortisol may produce clinically relevant cross-reactivity in 11ß-hydroxylase deficiency or following metyrapone challenge. Several anabolic steroids may produce clinically significant false positives on the testosterone assay, although interpretation is limited by sparse pharmacokinetic data for some of these drugs. Norethindrone therapy may impact immunoassay measurement of testosterone in women. Using two-dimensional similarity calculations, all compounds with high cross-reactivity also showed a high degree of similarity to the target molecule of the immunoassay.

Conclusions: Compounds producing cross-reactivity in steroid hormone immunoassays generally have a high degree of structural similarity to the target hormone. Clinically significant interactions can occur with structurally similar drugs (e.g., prednisolone and cortisol immunoassays; methyltestosterone and testosterone immunoassays) or with endogenous compounds such as 21-deoxycortisol that can accumulate to very high concentrations in certain disease conditions. Simple similarity calculations can help triage compounds for future testing of assay cross-reactivity.

Keywords: Anabolic agents, Estradiol, Glucocorticoids, Immunoassays, Progesterone, Similarity, Testosterone

\footnotetext{
*Correspondence: mkrasows@healthcare.uiowa.edu

'Department of Pathology, University of lowa Hospitals and Clinics, 200

Hawkins Drive, C-671 GH, lowa, IA 52242, USA

Full list of author information is available at the end of the article
} 


\section{Background}

Immunoassays are frequently used in laboratory medicine for quantitation of plasma/serum concentrations of steroid hormones such as cortisol, dehydroepiandrosterone (DHEA) sulfate, estradiol, progesterone, or testosterone $[1,2]$. A variety of immunoassay methods are available, ranging from enzyme-linked immunosorbent assays (ELISAs) to homogeneous immunoassays that can be run on highthroughput analyzers commonly found in hospital clinical laboratories [3]. The most common alternative approach for measurement of steroid hormones is chromatography (especially high-performance liquid chromatography, HPLC), either alone or in combination with mass spectrometry (MS) (HPLC/MS or simply LC/MS) [4-7]. An increasing number of clinical laboratories, particularly reference laboratories, utilize liquid chromatographytandem mass spectrometry (LC/MS/MS) for steroid hormone measurement [5]. LC/MS/MS provides a high degree of specificity for steroid hormone measurement. However, chromatography and mass spectrometry require specialized technical skill along with dedicated and often expensive instrumentation. Consequently, many clinical laboratories continue to use immunoassays for routine steroid hormone measurement.

One limitation of steroid hormone immunoassays is interference caused by compounds with structural similarity to the target steroid molecule against which the assay antibodies were generated [8]. Interfering molecules can be structurally related endogenous compounds (e.g., $6 \beta$-hydroxycortisol for a cortisol assay), drugs (including anabolic steroids and herbal medications), or natural products. Metabolites of these compounds may additionally cross-react. The manufacturers of commercially marketed steroid hormone immunoassays test a variety of endogenous and synthetic hormones for cross-reactivity and report this data in the assay package insert, typically as percent cross-reactivity or sometimes qualitatively (e.g., using a descriptor such as "cross-reacts"). The extent of cross-reactivity testing varies by assay and manufacturer without a clearly defined standard for which and how many compounds to test $[8,9]$.

While the package inserts or other manufacturers' documents collectively contain extensive data on marketed steroid hormone immunoassay cross-reactivity, studies of previously unreported interference with steroid hormone immunoassays have also appeared in the scientific literature. Examples include cross-reactivity of DHEA sulfate with testosterone immunoassays $[10,11]$, mifepristone with estradiol and testosterone enzyme immunoassays [12], and methylprednisolone with cortisol immunoassays [13].

In this study, we determine cross-reactivity of a variety of steroid and steroidal compounds (including anabolic steroids) to the Roche Diagnostics Elecsys immunoassays for cortisol, DHEA sulfate, estradiol, progesterone, and testosterone, and compare these results to other crossreactivity studies. We additionally utilize computational methodology to attempt to predict cross-reactivity of compounds for steroid hormone immunoassays, building on previous work using similarity analysis to predict crossreactivity of drug of abuse and therapeutic drug monitoring assays [14-17]. Our hypothesis is that a given compound is more likely to cross-react with an immunoassay if the compound shares a high level of structural similarity to the target molecule/hapten of the assay. To our knowledge, similarity analysis has not been applied to the prediction of cross-reactivity of immunoassays used to measure steroid hormones. Lastly, we discuss crossreactivity mostly likely to have impact on clinical testing using steroid hormone immunoassays.

\section{Methods}

\section{Chemicals}

Test compounds were obtained from Steraloids (Providence, Rhode Island, USA) or Sigma-Aldrich (St. Louis, Missouri, USA) (see Additional file 1 for sources and product numbers for all compounds tested). Interference studies were designed from NCCLS Guideline EP7-A [18], with test compounds spiked into normal human plasma. Each spiked sample was compared to the unadulterated sample, with the degree of interference expressed as percent cross-reactivity.

\section{Cross-reactivity Studies}

The assays tested experimentally were the Roche Diagnostics (Indianapolis, IN, USA) Cortisol, DHEA sulfate, Estradiol II, Progesterone II, and Testosterone II assays for Elecsys and Modular E170 analyzers. All assays were run using manufacturer specifications on Modular E170 analyzers. The complete details on assays are in the Additional file 1. Cross-reactivity was grouped into four broad categories: Strong Cross-Reactivity (5\% or greater), Weak Cross-Reactivity (0.5-4.9\%), Very Weak Cross-Reactivity (0.05-0.49\%), and Not Cross-Reactive $(<0.05 \%)$. Percent cross-reactivity is defined as the ratio of observed "steroid" to the amount of test compound added, multiplied by 100. These categories do not imply clinical significance but provide a broad framework to compare degree of cross-reactivity.

To estimate clinical significance of cross-reactivity, a literature search was conducted for studies that have reported plasma/serum concentrations of the potentially cross-reactive compounds. These included pharmacokinetic studies of steroidal drugs or investigations of steroid hormone concentrations in disorders such as $11 \beta$-hydroxylase or 21-hydroxylase deficiency. These references are reported in Tables 1, 2, 3, 4 and 5. 
Table 1 Cortisol immunoassay cross-reactivity

\begin{tabular}{|c|c|c|c|}
\hline Compound & Plasma/serum concentrations & $\begin{array}{l}\text { Cross-reactivity } \\
\text { in Roche assay }\end{array}$ & $\begin{array}{l}\text { Likelihood of clinically } \\
\text { significant cross-reactivity }\end{array}$ \\
\hline \multirow{2}{*}{$\begin{array}{l}\text { Cortisol (endogenous } \\
\text { compound) }\end{array}$} & • 62 - 194 ng/mL (morning) [19] & \multirow[t]{2}{*}{$100 \%$} & \multirow[t]{2}{*}{ High (assay target) } \\
\hline & • 23 - 119 ng/mL (afternoon) [19] & & \\
\hline 6-Methylprednisolone & $\begin{array}{l}\text { Up to } 1,000 \mathrm{ng} / \mathrm{mL} \text { after oral or } \\
\text { intravenous administration [20] }\end{array}$ & $249 \%$ & High \\
\hline Allotetrahydrocortisol & Unknown & $\begin{array}{l}165 \% \\
\text { (package insert) }\end{array}$ & $\begin{array}{l}\text { Unknown, serum/plasma concentrations } \\
\text { not reported }\end{array}$ \\
\hline $6 \beta$-Hydroxycortisol & Unknown & $\begin{array}{l}158 \% \\
\text { (package insert) }\end{array}$ & $\begin{array}{l}\text { Unknown, serum/plasma concentrations } \\
\text { not reported }\end{array}$ \\
\hline Prednisolone & $\begin{array}{l}\text { Up to } 400 \mathrm{ng} / \mathrm{mL} \text { in pediatric transplant } \\
\text { patients [21] }\end{array}$ & $148 \%$ & High \\
\hline \multirow[t]{2}{*}{ 21-Deoxycortisol } & • $0.28-0.43 \mathrm{ng} / \mathrm{mL}$ (pediatric controls) [22] & \multirow{2}{*}{$\begin{array}{l}45.4 \% \\
\text { (package insert) }\end{array}$} & \multirow{2}{*}{$\begin{array}{l}\text { Low, except in patients with 21-hydroxylase } \\
\text { deficiency }\end{array}$} \\
\hline & $\begin{array}{l}\text { - Up to } 140 \mathrm{ng} / \mathrm{mL} \text { (patients with } \\
\text { 21-hydroxylase deficiency) [22] }\end{array}$ & & \\
\hline Fludrocortisone & • 0.36 ng/ml after single dose [23] & $7.7 \%$ & Low \\
\hline $5 \beta$-Dihydrocorticosterone & Unknown & $4.9 \%$ & $\begin{array}{l}\text { Unknown, serum/plasma concentrations not } \\
\text { reported }\end{array}$ \\
\hline \multirow[t]{2}{*}{ Corticosterone } & • 0.18 - $2.0 \mathrm{ng} / \mathrm{mL}$ (18 years and younger) [24] & \multirow[t]{2}{*}{$4.6 \%$} & \multirow[t]{2}{*}{ Low } \\
\hline & $\cdot 0.53-1.6 \mathrm{ng} / \mathrm{mL}$ (<18 years) [24] & & \\
\hline \multirow[t]{3}{*}{ 11-Deoxycortisol } & • $0.17-1.8$ ng/mL (pediatric controls) [22] & \multirow[t]{3}{*}{$4.6 \%$} & \multirow{3}{*}{$\begin{array}{l}\text { Low, except in patients following metyrapone } \\
\text { challenge or who have } 11 \beta \text {-hydroxylase deficienc, }\end{array}$} \\
\hline & $\begin{array}{l}\text { - Up to } 63 \mathrm{ng} / \mathrm{mL} \text { (patients with } \\
11 \beta \text {-hydroxylase deficiency) [22] }\end{array}$ & & \\
\hline & $\begin{array}{l}\text { - Up to } 250 \mathrm{ng} / \mathrm{mL} \text { (following } \\
\text { metyrapone challenge) [25] }\end{array}$ & & \\
\hline Canrenone & $\begin{array}{l}10-1,000 \mathrm{ng} / \mathrm{mL} \text { in patients receiving } \\
\text { spironolactone }[26-28]\end{array}$ & $1.8 \%$ & $\begin{array}{l}\text { Low, except if cortisol measured during peak } \\
\text { canrenone concentrations }\end{array}$ \\
\hline \multirow[t]{2}{*}{ 17-Hydroxyprogesterone } & • 0.08 - $2.0 \mathrm{ng} / \mathrm{mL}$ (pediatric controls) [22] & \multirow[t]{2}{*}{$1.6 \%$} & \multirow{2}{*}{$\begin{array}{l}\text { Low, except in patients with 21-hydroxylase } \\
\text { deficiency }\end{array}$} \\
\hline & $\begin{array}{l}\text { - Up to } 1,005 \mathrm{ng} / \mathrm{mL} \text { (21-hydroxylase } \\
\text { deficiency) [22] }\end{array}$ & & \\
\hline Formestane & Up to $14 \mathrm{ng} / \mathrm{mL}$ in breast cancer patients [29] & $1.2 \%$ & Low \\
\hline \multirow[t]{2}{*}{ Androstenedione } & - Up to $0.86 \mathrm{ng} / \mathrm{mL}$ before onset of puberty [30] & \multirow[t]{2}{*}{$0.9 \%$} & \multirow[t]{2}{*}{ Low } \\
\hline & $\begin{array}{l}\text { - Up to } 3.2 \mathrm{ng} / \mathrm{mL} \text { in 21-hydroxylase } \\
\text { deficiency [30] }\end{array}$ & & \\
\hline Prednisone & $\begin{array}{l}\text { Up to } 57 \mathrm{ng} / \mathrm{mL} \text { in pediatric transplant } \\
\text { patients receiving prednisolone [21] }\end{array}$ & $0.3 \%$ & Low \\
\hline
\end{tabular}

\section{Two-dimensional (2D) Similarity analysis}

Comparison of similarity of test molecules to the target compounds of the steroid immunoassays used twodimensional (2D) similarity analysis, which determines the similarity between molecules independent of any in vitro data [52-54]. These methods have been applied in our previous publications on cross-reactivity of drug of abuse and therapeutic drug monitoring immunoassays [14-17]. 2D similarity searching used the "find similar molecules by fingerprints" protocol in Discovery Studio versions 2.5.5 and 3.5 (Accelrys, Inc., San Diego, California, USA). MDL public keys (a specific 2D similarity algorithm) were used with the Tanimoto similarity coefficient (ranging from 0 to 1 with 1 being maximally similar and 0 being maximally dissimilar) and an input query. It should be noted that 2D similarity algorithms do not distinguish between diastereomers and enantiomeric pairs. 2D similarity for each test compound was compared to the target molecule of the immunoassay (e.g., estradiol or progesterone) undergoing analysis. Figure 1 illustrates 2D similarity of five compounds to cortisol.

\section{Results}

\section{Cortisol immunoassay}

Based on package insert data and the experimental testing in the current study, six compounds produce crossreactivity of $5 \%$ of greater on the Roche Elecsys Cortisol assay at a test concentration of $1 \mu \mathrm{g} / \mathrm{mL}(1,000 \mathrm{ng} / \mathrm{mL})$ : 6ß-hydroxycortisol, allotetrahydrocortisol, 21-deoxycortisol, 
Table 2 DHEA sulfate immunoassay cross-reactivity

\begin{tabular}{|c|c|c|c|}
\hline Compound & Plasma/serum concentrations & $\begin{array}{l}\text { Cross-reactivity in } \\
\text { Roche assay }\end{array}$ & $\begin{array}{l}\text { Likelihood of clinically } \\
\text { significant cross-reactivity }\end{array}$ \\
\hline \multirow[t]{3}{*}{ DHEA sulfate } & • Up to 6,070 ng/mL (infants) [31] & \multirow[t]{3}{*}{$100 \%$} & \multirow[t]{3}{*}{ High (assay target) } \\
\hline & • $5-4,070 \mathrm{ng} / \mathrm{mL}$ (females $>1$ year old) [31] & & \\
\hline & • $5-4,920 \mathrm{ng} / \mathrm{mL}$ (males > 1 year old) [31] & & \\
\hline \multirow[t]{2}{*}{ Pregnenolone sulfate } & • 21 - 84 ng/mL (adult controls) [32] & \multirow[t]{2}{*}{$2.1 \%$} & \multirow{2}{*}{$\begin{array}{l}\text { Low, possible minor effect around } \\
\text { time of parturition. }\end{array}$} \\
\hline & • Up to $1,580 \mathrm{ng} / \mathrm{mL}$ in pregnancy [33] & & \\
\hline \multirow[t]{2}{*}{ 17-Hydroxyprogesterone } & • $0.1-2.0$ ng/mL (pediatric controls) [22] & \multirow[t]{2}{*}{$0.08 \%$} & \multirow{2}{*}{$\begin{array}{l}\text { Low, possible minor effect in } \\
21 \text {-hydroxylase deficiency. }\end{array}$} \\
\hline & • Up to 1,005 ng/mL (21-hydroxylase deficiency) [22] & & \\
\hline \multirow[t]{3}{*}{ 17-Hydroxypregnenolone } & - Up to $4.3 \mathrm{ng} / \mathrm{ml}$ in healthy females [34,35] & \multirow[t]{3}{*}{$0.05 \%$} & \multirow[t]{3}{*}{ Low } \\
\hline & - Up to $4.8 \mathrm{ng} / \mathrm{mL}$ in healthy males $[34,35]$ & & \\
\hline & - Up to $100 \mathrm{ng} / \mathrm{mL}$ in premature infants [36] & & \\
\hline
\end{tabular}

fludrocortisone, prednisolone, and 6-methylprednisolone (Figure 1; Table 1; Additional file 1). Seventeen additional compounds produced cross-reactivity between 0.5 and $4.9 \%$.

Using the cross-reactivity values, the apparent cortisol concentration that could be produced on the Roche Elecsys immunoassay was estimated for compounds based on published serum/plasma concentrations, if available (Figure 2A, Table 1). Prednisolone and 6-methylprednisolone are both predicted to produce substantial apparent cortisol concentrations on the Roche immunoassay at serum/ plasma concentrations typical in patients administered these drugs. Falsely elevated cortisol readings may also occur with 21-deoxycortisol in patients with 21-hydroxylase deficiency and with 11-deoxycortisol following metyrapone challenge (Figure 2A, Table 1). In both scenarios, clinically significant falsely elevated cortisol measurements are most likely only when 21-deoxycortisol or 11-deoxycortisol are at the high end of serum/plasma concentrations reported in the literature.

The majority of the compounds with strong crossreactivity for the Roche Elecsys Cortisol assay had 2Dsimilarities to cortisol of 0.867 or higher (Figure 2B). Only one compound (tetrahydrocortisone) had a 2D- similarity to cortisol higher than 0.867 but was not cross-reactive in our study.

\section{DHEA sulfate immunoassay}

No compounds produced greater than $5 \%$ cross-reactivity on the Roche Elecsys DHEA sulfate immunoassay at a test concentration of $50 \mu \mathrm{g} / \mathrm{mL}(50,000 \mathrm{ng} / \mathrm{mL})$, and only two compounds (estropipate and pregnenolone sulfate) produced greater than $0.5 \%$ cross-reactivity (Table 2 ; Additional file 1). Twenty-six compounds produced crossreactivity between 0.05 and $0.5 \%$. This group of compounds with very weak cross-reactivity included anabolic steroids (nandrolone), androstanes (androstenedione, androsterone sulfate), estranes (estrone-3-sulfate), and pregnanes (17 $\alpha$ hydroxypregnenolone).

Using the cross-reactivity values, the apparent DHEA sulfate concentration that could be produced on the Roche Elecsys immunoassay was estimated for compounds based on published serum/plasma concentrations, if available (Figure 3A, Table 2). In only two scenarios was the apparent DHEA sulfate concentration predicted to fall within the reference ranges for DHEA sulfate - pregnenolone sulfate in pregnancy and 17-hydroxyprogesterone in patients with 21-hydroxylase deficiency (Figure 3A).

Table 3 Estradiol immunoassay cross-reactivity

\begin{tabular}{|c|c|c|c|}
\hline Compound & Plasma/serum concentrations & $\begin{array}{l}\text { Cross-reactivity in } \\
\text { Roche assay }\end{array}$ & $\begin{array}{l}\text { Likelihood of clinically } \\
\text { significant cross-reactivity }\end{array}$ \\
\hline \multirow[t]{3}{*}{ Estradiol (endogenous compound) } & • $0.01-0.04$ ng/mL (males) [37] & $100 \%$ & High (assay target) \\
\hline & • $0.013-0.50 \mathrm{ng} / \mathrm{mL}$ (premenopausal females) [37] & & \\
\hline & - Up to 4.3 ng/mL (pregnancy) [37] & & \\
\hline \multirow[t]{2}{*}{ Estrone } & • Up to $0.06 \mathrm{ng} / \mathrm{mL}$ (males) [24] & $0.54 \%$ & Low \\
\hline & - Up to $0.2 \mathrm{ng} / \mathrm{mL}$ (females) [24] & & \\
\hline Ethinyl estradiol & Up to $0.1 \mathrm{ng} / \mathrm{mL}$ while on medication [38-41] & $0.23 \%$ & Low \\
\hline \multirow[t]{2}{*}{ Estriol } & - Up to $18 \mathrm{ng} / \mathrm{mL}$ in pregnancy [42] & $0.09 \%$ & Possible contribution in pregnancy \\
\hline & - Up to $2.4 \mathrm{ng} / \mathrm{mL}$ in non-pregnant females [43] & & \\
\hline
\end{tabular}


Table 4 Progesterone immunoassay cross-reactivity

\begin{tabular}{|c|c|c|c|}
\hline Compound & Plasma/serum concentrations & $\begin{array}{l}\text { Cross-reactivity } \\
\text { in Roche assay }\end{array}$ & $\begin{array}{l}\text { Likelihood of clinically } \\
\text { significant cross-reactivity }\end{array}$ \\
\hline \multirow[t]{2}{*}{ Progesterone } & $\cdot 0.2-1.4 \mathrm{ng} / \mathrm{mL}$ (males) [44] & \multirow[t]{2}{*}{$100 \%$} & \multirow[t]{2}{*}{ High (assay target) } \\
\hline & - Up to $27 \mathrm{ng} / \mathrm{mL}$ (women) [44] & & \\
\hline $5 \beta$-Dihydroprogesterone & Up to $0.8 \mathrm{ng} / \mathrm{mL}$ in adults [45] & $18.2 \%$ & $\begin{array}{l}\text { Possible significant contribution for individuals } \\
\text { with progesterone concentrations on the } \\
\text { lower end of reference interval }\end{array}$ \\
\hline \multirow[t]{2}{*}{ 17-Hydroxyprogesterone } & • $0.08-2.0 \mathrm{ng} / \mathrm{mL}$ (pediatric controls) [22] & \multirow[t]{2}{*}{$1.2 \%$} & \multirow{2}{*}{$\begin{array}{l}\text { Low, except in patients with } \\
\text { 21-hydroxylase deficiency }\end{array}$} \\
\hline & $\begin{array}{l}\text { - Up to } 1,005 \mathrm{ng} / \mathrm{mL} \\
\text { (21-hydroxylase deficiency) [22] }\end{array}$ & & \\
\hline Pregnanolone & Up to $17 \mathrm{ng} / \mathrm{mL}$ in women [33] & $0.90 \%$ & Low \\
\hline Allopregnanolone & Up to $29 \mathrm{ng} / \mathrm{mL}$ in women [33] & $0.82 \%$ & Low \\
\hline Medroxyprogesterone & $\begin{array}{l}\text { Up to } 100 \mathrm{ng} / \mathrm{mL} \text { following } \\
\text { dosing in women [46] }\end{array}$ & $0.67 \%$ & $\begin{array}{l}\text { Possible significant contribution for individuals } \\
\text { with progesterone concentrations on the } \\
\text { lower end of reference interval }\end{array}$ \\
\hline \multirow[t]{2}{*}{ Corticosterone } & • $0.18-2.0 \mathrm{ng} / \mathrm{mL}$ (18 years and younger) [24] & \multirow[t]{2}{*}{$0.54 \%$} & \multirow[t]{2}{*}{ Low } \\
\hline & $\cdot 0.53-1.6 \mathrm{ng} / \mathrm{mL}$ (<18 years) [24] & & \\
\hline \multirow[t]{3}{*}{ 11-Deoxycortisol } & • $0.17-1.8 \mathrm{ng} / \mathrm{mL}$ (pediatric controls) [22] & \multirow[t]{3}{*}{$0.39 \%$} & \multirow{3}{*}{$\begin{array}{l}\text { Low, except in patients following } \\
\text { metyrapone challenge or who have } \\
11 \beta \text {-hydroxylase deficiency }\end{array}$} \\
\hline & • Up to 63 ng/mL (11ß-hydroxylase deficiency) [22] & & \\
\hline & - Up to $250 \mathrm{ng} / \mathrm{mL}$ (metyrapone challenge) [25] & & \\
\hline Nandrolone & $\begin{array}{l}\text { Up to } 5.16 \mathrm{ng} / \mathrm{mL} \text { in men following intramuscular } \\
\text { injection [47] }\end{array}$ & $0.17 \%$ & Low \\
\hline Pregnenolone & Up to 3.27 ng/mL in women [33] & $0.12 \%$ & Low \\
\hline Exemestane & Up to $441 \mathrm{ng} / \mathrm{mL}$ in post-menopausal women [48] & $0.09 \%$ & $\begin{array}{l}\text { Possible significant effect if progesterone } \\
\text { measured near peak of exemestane } \\
\text { plasma concentration }\end{array}$ \\
\hline \multirow[t]{2}{*}{ Androstenedione } & - Up to $0.86 \mathrm{ng} / \mathrm{mL}$ before onset of puberty [30] & \multirow[t]{2}{*}{$0.09 \%$} & \multirow[t]{2}{*}{ Low } \\
\hline & • Up to 3.2 ng/mL in 21-hydroxylase deficiency [30] & & \\
\hline
\end{tabular}

Table 5 Testosterone immunoassay cross-reactivity

\begin{tabular}{|c|c|c|c|}
\hline Compound & Plasma/serum concentrations & $\begin{array}{l}\text { Cross-reactivity } \\
\text { in Roche assay }\end{array}$ & $\begin{array}{l}\text { Likelihood of clinically } \\
\text { significant cross-reactivity }\end{array}$ \\
\hline \multirow{2}{*}{$\begin{array}{l}\text { Testosterone } \\
\text { (endogenous compound) }\end{array}$} & $\cdot 0$ - $10 \mathrm{ng} / \mathrm{mL}$ (males) [49] & \multirow[t]{2}{*}{$100 \%$} & \multirow[t]{2}{*}{ High (assay target) } \\
\hline & • 0 - 0.5 ng/mL (females) [49] & & \\
\hline Methyltestosterone & $\begin{array}{l}\text { Up to } 40 \mathrm{ng} / \mathrm{mL} \text { following single } \\
\text { dose [50] }\end{array}$ & $12.2 \%$ & High, especially if measured during peak concentration \\
\hline Boldenone & $\begin{array}{l}\text { Up to } 1.1 \mathrm{ng} / \mathrm{mL} \text { in horses following } \\
\text { dosing }[51]\end{array}$ & $7.2 \%$ & $\begin{array}{l}\text { Likely low, although there is lack of human pharmacokinetic } \\
\text { data }\end{array}$ \\
\hline 19-Norclostebol & Unknown & $6.7 \%$ & Unknown, no human pharmacokinetic data available \\
\hline Norethindrone & $\begin{array}{l}\text { Up to } 20 \mathrm{ng} / \mathrm{mL} \text { while on medication } \\
\text { [39-41] }\end{array}$ & $6.7 \%$ & $\begin{array}{l}\text { Possible significant contribution in women taking } \\
\text { norethindrone, especially if specimen drawn near } \\
\text { peak of norethindrone concentration }\end{array}$ \\
\hline $11 \beta$-Hydroxytestosterone & Unknown & $5.5 \%$ & Unknown, no human pharmacokinetic data available \\
\hline Methandrostenolone & Unknown & $5.4 \%$ & Unknown, no human pharmacokinetic data available \\
\hline Normethandrolone & Unknown & $5.4 \%$ & Unknown, no human pharmacokinetic data available \\
\hline Nandrolone & Up to $5.16 \mathrm{ng} / \mathrm{mL}[47]$ & $2.1 \%$ & Low \\
\hline \multirow[t]{2}{*}{ Androstenedione } & $\begin{array}{l}\text { - Up to } 0.86 \mathrm{ng} / \mathrm{mL} \text { before onset of } \\
\text { puberty [30] }\end{array}$ & \multirow[t]{2}{*}{$1.2 \%$} & \multirow[t]{2}{*}{ Low } \\
\hline & $\begin{array}{l}\text { - Up to } 3.2 \mathrm{ng} / \mathrm{mL} \text { in 21-hydroxylase } \\
\text { deficiency [30] }\end{array}$ & & \\
\hline
\end{tabular}




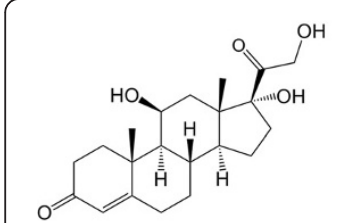

Cortisol (assay target)<smiles>CC(O)C(=O)[C@]1(O)CC[C@H]2[C@@H]3CCC4=CC(=O)CC[C@]4(C)[C@H]3[C@H](O)C[C@]21C</smiles>

21-Deoxycortisol Similarity 0.867 Strong cross-reactivity

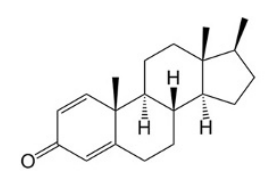

Boldenone Similarity 0.778 Very weak cross-reactivity

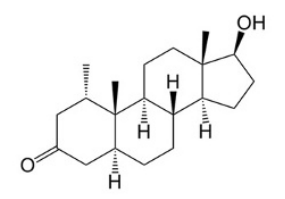

Mesterolone Similarity 0.698 No cross-reactivity

Figure 1 Illustration of two-dimensional similarity to cortisol. The figure depicts chemical structures of cortisol, 6-methylprednisolone, 21-deoxycortisol, 17a-hydroxyprogesterone, boldenone, and mesterolone. Below each compound is the two-dimensional similarity to cortisol and the degree of cross-reactivity to the Roche Elecsys Cortisol immunoassay.

The two compounds with the highest percent crossreactivity in the DHEA sulfate immunoassay (estropipate and pregnenolone sulfate) had higher 2D similarities to DHEA sulfate than all 56 compounds classified as noncross-reactive (Figure 3B; Additional file 1). Only 4 of 20 compounds with very weak cross-reactivity has $2 \mathrm{D}$ similarity to DHEA sulfate greater than 0.8 . All non-cross-reactive compounds had 2D similarities less than 0.8 .

\section{Estradiol immunoassay}

Only estrone $(0.54 \%)$ produced greater than $0.5 \%$ crossreactivity on the Roche Elecsys Estradiol II immunoassay at a challenge of $1 \mu \mathrm{g} / \mathrm{mL}(1,000 \mathrm{ng} / \mathrm{mL}$ ) (Table 3; Additional file 1). Estriol, estropipate, ethinyl estradiol, 2-methoxyestradiol, $17 \beta$-estradiol-17-valerate, and $17 \beta$-estradiol-3, 17-disulfate each produced very weak cross-reactivity between 0.05 and $0.5 \%$. The aromatase inhibitors exemestane, formestane, and letrozole produced no detectable crossreactivity.
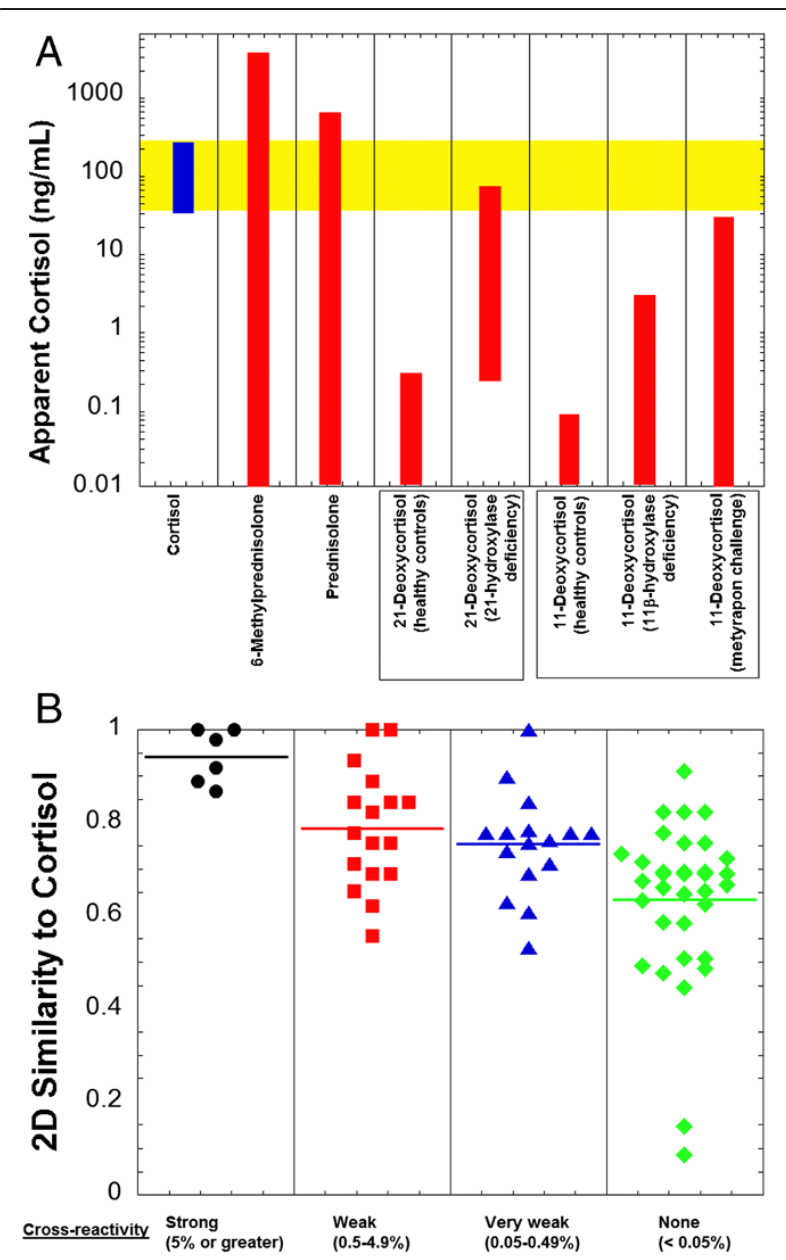

Figure 2 Cortisol immunoassay cross-reactivity and similarity predictions. A. The plot shows the cortisol reference range for adults (highlighted in yellow) in comparison to the predicted apparent cortisol concentrations produced on the Roche Elecsys Cortisol assay by 6-methylprednisolone, prednisolone, 21-deoxycortisol (healthy controls and patients with 21-hydroxylase deficiency), and 11-deoxycortisol (healthy controls, patients with 11ß-hydroxylase deficiency, and following metyapon challenge). Table 1 contains the concentration ranges and percent cross-reactivity values from which the estimated apparent cortisol concentrations are derived. B. Two-dimensional similarity of compounds to cortisol is shown, sorted by degree of cross-reactivity in the Roche Cortisol assay (horizontal line in each column indicates average similarity within that group). Similarity values vary from 0 to 1 , with 1 being maximally similar. The compounds are subdivided into categories of strong cross-reactivity ( $5 \%$ or greater, black circles), weak cross-reactivity $(0.5-4.9 \%$, red squares), very weak cross-reactivity (0.05-0.49\%, blue triangles), and no cross-reactivity $(<0.05 \%$, green diamonds) to the Roche Cortisol assay (complete list of compounds and associated cross-reactivities and $2 \mathrm{D}$ similarities is in Additional file 1).

Using the cross-reactivity values, the apparent estradiol concentration that could be produced on the Roche Elecsys immunoassay was estimated for compounds based on published serum/plasma concentrations, if available (Figure 4A, Table 3). No compound was predicted to 

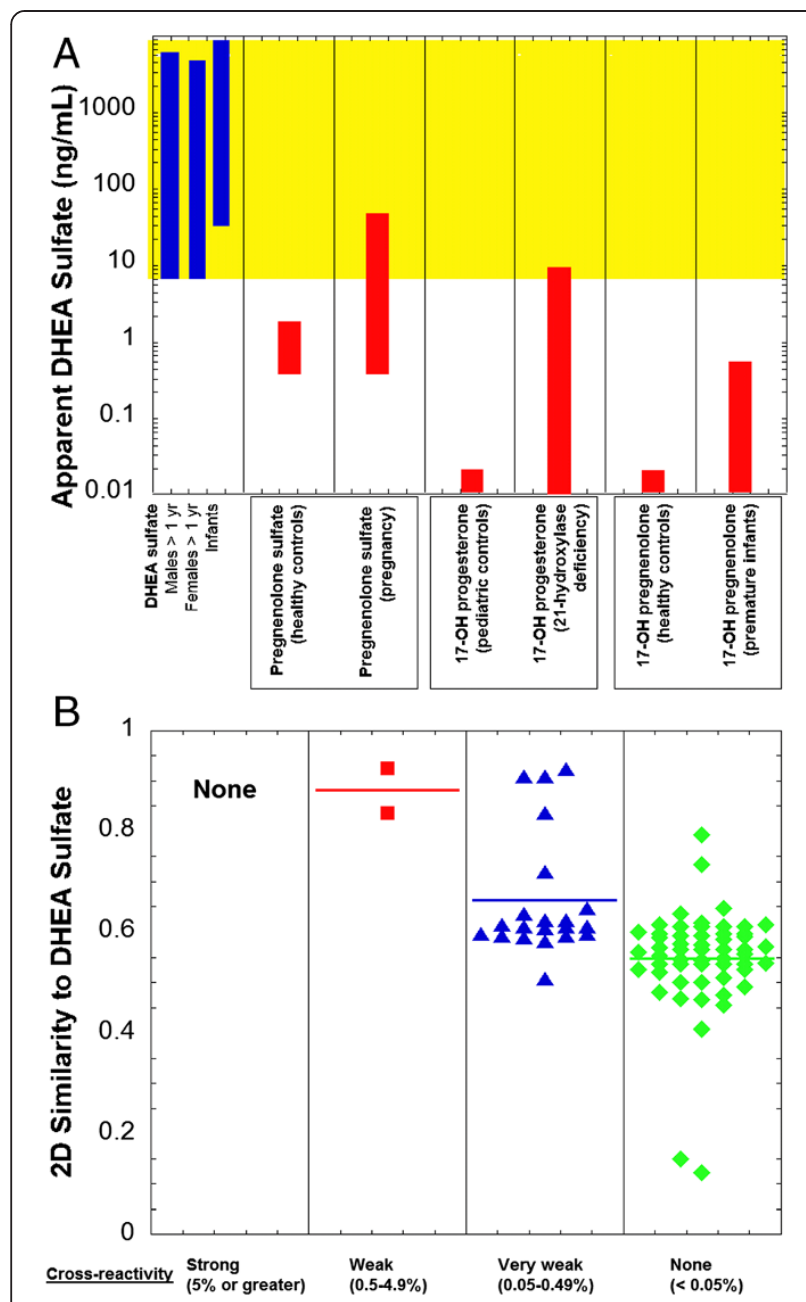

Figure 3 DHEA sulfate immunoassay cross-reactivity and similarity predictions. A. The plot shows the DHEA sulfate reference range for males greater than 1 year old, females greater than 1 year old, and infants in comparison to the predicted apparent DHEA sulfate concentrations produced on the Roche Elecsys DHEA sulfate assay by pregnenolone sulfate (healthy controls and in pregnancy), 17-hydroxyprogesterone (pediatric controls and patients with 21-hydroxylase deficiency), and 17-hydroxypregnenolone (healthy controls and premature infants). Table 2 contains the concentration ranges and percent cross-reactivity values from which the estimated apparent DHEA sulfate concentrations are derived. B. Two-dimensional similarity of compounds to DHEA sulfate is shown, sorted by degree of cross-reactivity in the Roche DHEA sulfate assay (horizontal line in each column indicates average similarity within that group). Similarity values vary from 0 to 1 , with 1 being maximally similar. The compounds are subdivided into categories of strong cross-reactivity (5\% or greater, black circles), weak cross-reactivity (0.5-4.9\%, red squares), very weak cross-reactivity ( $0.05-0.49 \%$, blue triangles), and no cross-reactivity ( $<0.05 \%$, green diamonds) to the Roche DHEA sulfate assay (complete list of compounds and associated cross-reactivities and 2D similarities is in Additional file 1).

produce estradiol concentrations within the reference range for males or females. Even estriol, which can reach high concentrations in pregnancy, likely produces little or
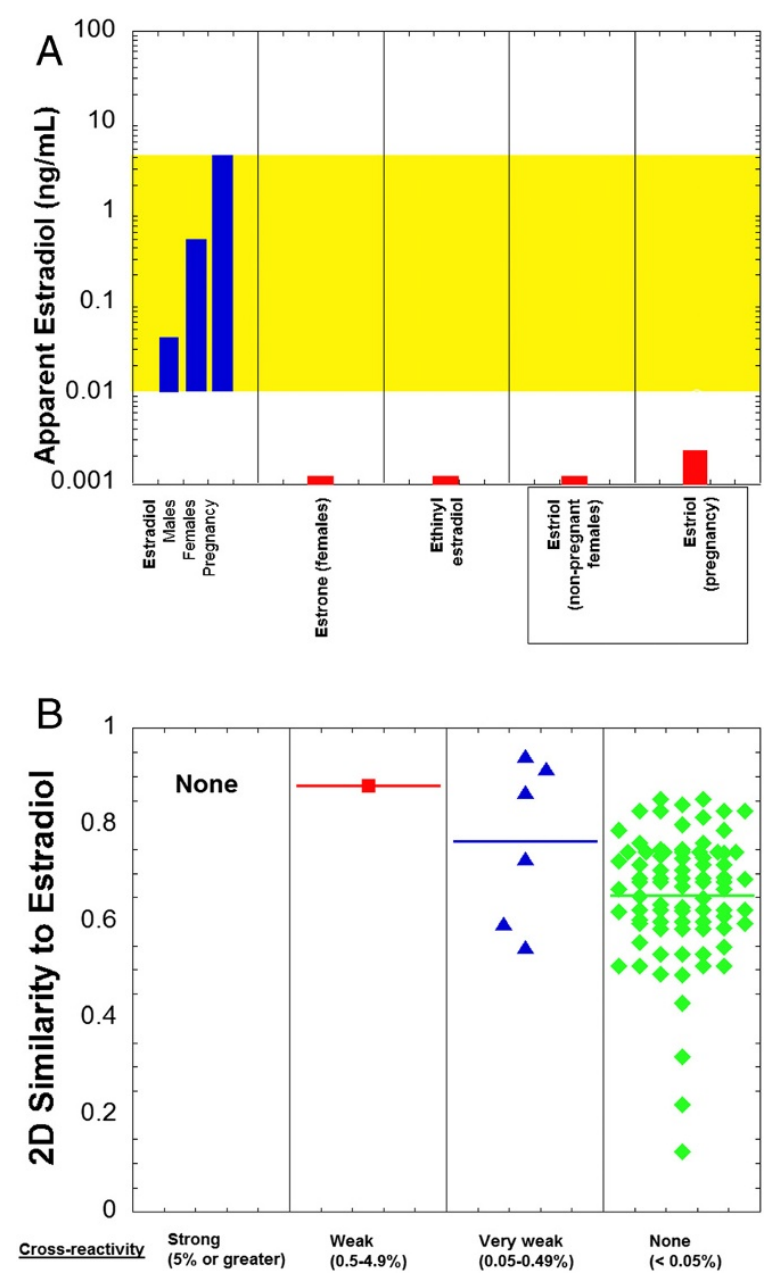

Figure 4 Estradiol immunoassay cross-reactivity and similarity predictions. A. The plot shows the estradiol reference ranges for males, non-pregnant females, and pregnant females (highlighted in yellow) in comparison to the predicted apparent estradiol concentrations produced on the Roche Elecsys Estradiol II assay by estrone (females), ethinyl estradiol, and estriol (non-pregnant and pregnant females). Table 3 contains the concentration ranges and percent cross-reactivity values from which the estimated apparent estradiol concentrations are derived. B. Two-dimensional similarity of compounds to estradiol is shown, sorted by degree of cross-reactivity in the Roche Estradiol II assay (horizontal line in each column indicates average similarity within that group). Similarity values vary from 0 to 1 , with 1 being maximally similar. The compounds are subdivided into categories of strong cross-reactivity ( $5 \%$ or greater, black circles), weak cross-reactivity (0.5-4.9\%, red squares), very weak cross-reactivity $(0.05-0.49 \%$, blue triangles), and no cross-reactivity ( $<0.05 \%$, green diamonds) to the Roche Estradiol II assay (complete list of compounds and associated cross-reactivities and 2D similarities is in Additional file 1).

no clinically significant impact on the Roche estradiol immunoassay due to low cross-reactivity. The 2D similarities of estrone (0.882), ethinyl estradiol (0.943), and estriol (0.917) were higher than any of the compounds that were not cross-reactive on the Roche assay (Figure 4B). 


\section{Progesterone immunoassay}

$5 \beta$-Dihydroprogesterone (5 $\beta$-pregnan-3,20-dione) was the most cross-reactive compound for the Roche Elecsys Progesterone II immunoassay at a challenge of $1 \mu \mathrm{g} / \mathrm{mL}$ $(1,000 \mathrm{ng} / \mathrm{mL}$ ), with a cross-reactivity of $18.2 \%$ (Table 4 ; Additional file 1). 17-Hydroxyprogesterone, $5 \alpha$-pregnan3-ol-20-one, 5 $\alpha$-pregnan-3,20-dione, 5 $\alpha$-pregnenolone, medroxyprogesterone, and pregnanolone each produced weak cross-reactivity between $0.5 \%$ and $4.9 \%$. An additional twenty-two compounds produced very weak cross-reactivity (0.05-0.49\%).

Using the cross-reactivity values, the apparent progesterone concentration that could be produced on the Roche Elecsys immunoassay was estimated for compounds based on published serum/plasma concentrations, if available (Figure 5A, Table 4). The most significant apparent progesterone concentrations were estimated to occur with 17-hydroxyprogesterone in patients with 21-hydroxylase deficiency and for 11-deoxycortisol following metyrapone challenge. $5 \beta$-Dihydroprogesterone and allopregnanolone both may produce apparent progesterone concentrations of approximately $0.2 \mathrm{ng} / \mathrm{mL}$, but likely only when these compounds are the highest end of what can occur physiologically (Table 4). Two medications, medroxyprogesterone and exemestane, each may have cross-reactivity on the progesterone immunoassay that can produce apparent progesterone concentration of approximately $0.5 \mathrm{ng} / \mathrm{mL}$.

$5 \beta$-Dihydroprogesterone had higher $2 \mathrm{D}$ similarity to progesterone than any compound that was not crossreactive (Figure 5B; Additional file 1). All compounds with strong or weak cross-reactivity had $2 \mathrm{D}$ similarities of 0.722 or higher to progesterone. In contrast, only 27 of 55 compounds that were non-cross-reactive on the Roche progesterone immunoassay had 2D similarity of 0.722 or higher to progesterone.

\section{Testosterone immunoassay}

Anabolic steroids were well-represented among compounds cross-reacting with the Roche Elecsys Testosterone II immunoassay at a test concentration of $0.1 \mu \mathrm{g} / \mathrm{mL}$ (100 ng/mL) (Table 5; Additional file 1). Seven compounds (boldenone, 19-norclostebol, dianabol, methyltestosterone, norethindrone, normethandrolone, and $11 \beta$-hydroxytestosterone) produced cross-reactivity of $5 \%$ or greater. Nine additional compounds produced cross-reactivity between $0.5 \%$ and $4.9 \%$. Examples of anabolic steroids that produced no detectable cross-reactivity included anasterone (oxymetholone), stanozolol, and turinabol.

Using the cross-reactivity values, the apparent testosterone concentration that could be produced on the Roche Elecsys Testosterone II immunoassay was estimated for compounds based on published serum/plasma concentrations, if available (Figure 6A, Table 5). There is limited
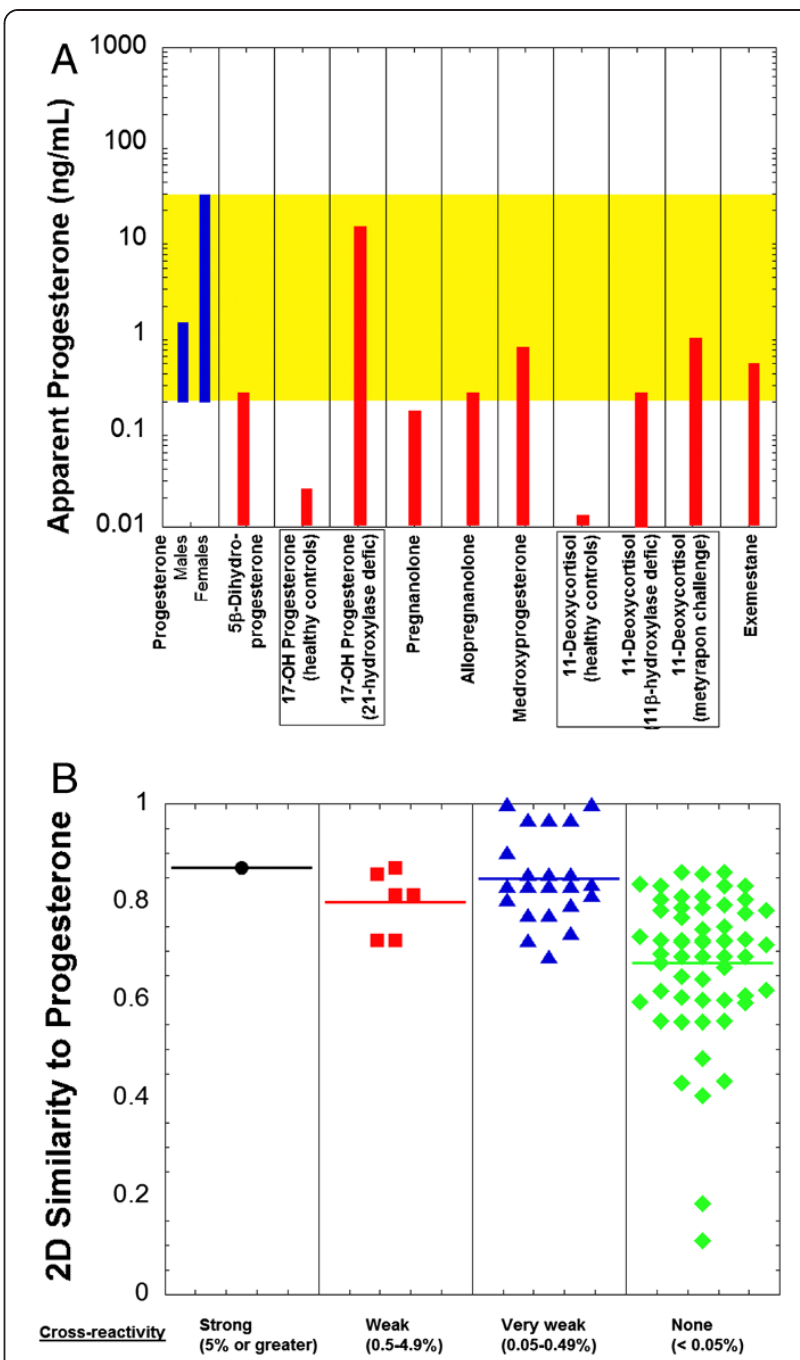

Figure 5 Progesterone immunoassay cross-reactivity and similarity predictions. A. The plot shows the progesterone reference range for adult males and females (highlighted in yellow) in comparison to the predicted apparent progesterone concentrations produced on the Roche Elecsys Progesterone II assay by $5 \beta$-dihydroprogesterone, 17-hydroxyprogesterone (pediatric controls and patients with 21-hydroxylase deficiency), pregnanolone, allopregnanolone, medroxyprogesterone, 11deoxycortisol (healthy controls, patients with $11 \beta$-hydroxylase deficiency, and following metyapon challenge), and exemestane. Table 4 contains the concentration ranges and percent cross-reactivity values from which the estimated apparent progesterone concentrations are derived. B. Two-dimensional similarity of compounds to progesterone is shown, sorted by degree of cross-reactivity in the Roche Progesterone II assay (horizontal line in each column indicates average similarity within that group). Similarity values vary from 0 to 1 , with 1 being maximally similar. The compounds are subdivided into categories of strong cross-reactivity (5\% or greater, black circles), weak cross-reactivity (0.5-4.9\%, red squares), very weak cross-reactivity (0.05$0.49 \%$, blue triangles), and no cross-reactivity $(<0.05 \%$, green diamonds) to the Roche Progesterone II assay (complete list of compounds and associated cross-reactivities and 2D similarities is in Additional file 1). 

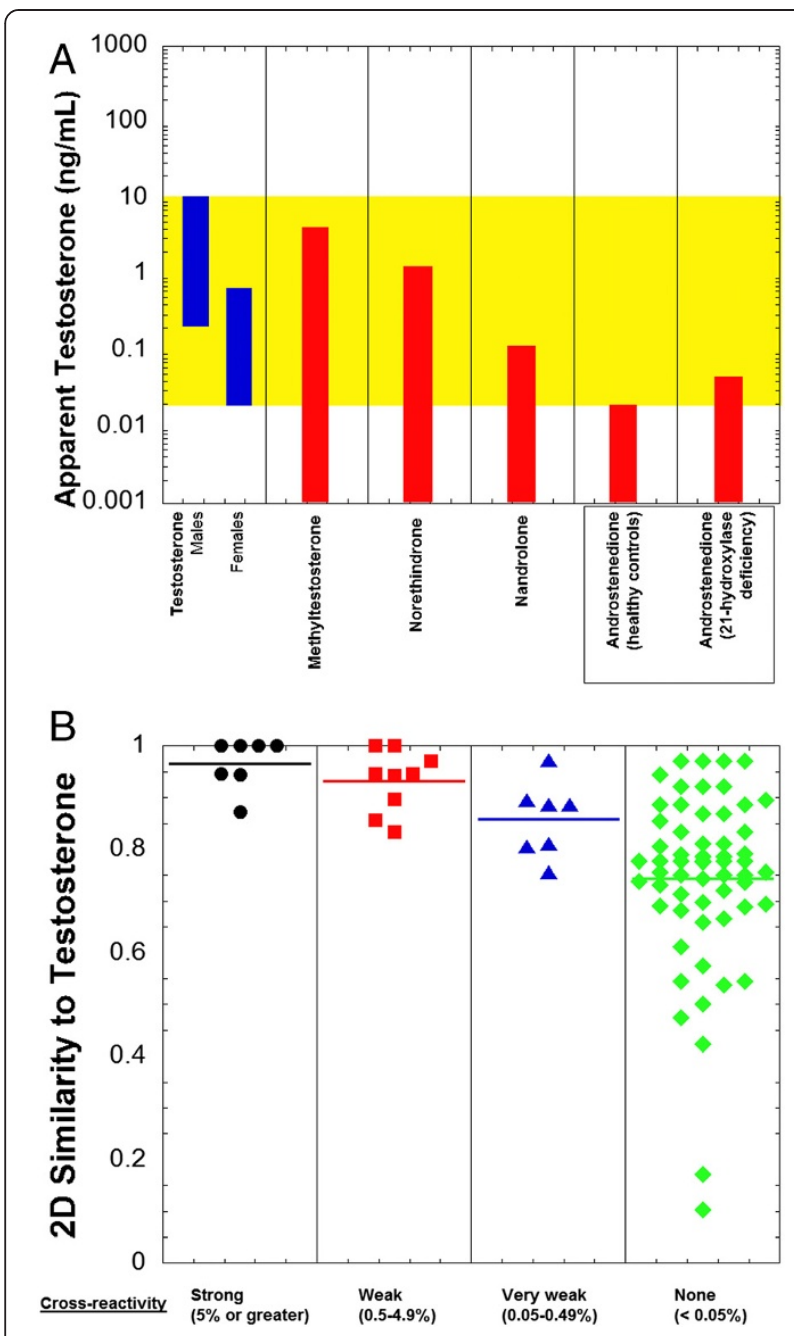

Figure 6 Testosterone immunoassay cross-reactivity and similarity predictions. A. The plot shows the testosterone reference range for males and females (highlighted in yellow) in comparison to the predicted apparent testosterone concentrations produced on the Roche Elecsys Testosterone II assay by methyltestosterone, norethindrone, nandrolone, and androstenedione (healthy controls and patients with 21-hydroxylase deficiency). Table 5 contains the concentration ranges and percent cross-reactivity values from which the estimated apparent testosterone concentrations are derived. B. Two-dimensional similarity of compounds to testosterone is shown, sorted by degree of cross-reactivity in the Roche Testosterone II assay (horizontal line in each column indicates average similarity within that group). Similarity values vary from 0 to 1 , with 1 being maximally similar. The compounds are subdivided into categories of strong cross-reactivity (5\% or greater, black circles), weak cross-reactivity (0.5-4.9\%, red squares), very weak cross-reactivity (0.05-0.49\%, blue triangles), and no cross-reactivity ( $<0.05 \%$, green diamonds) to the Roche Testosterone II assay (complete list of compounds and associated cross-reactivities and 2D similarities is in Additional file 1).

published data on serum/plasma concentrations of some of the anabolic steroids, with generally more focus on measurement of these compounds in urine samples, usually for the purposes of detecting use as performance-enhancing drugs in competitive athletics [55-57]. Of the anabolic steroids for which serum/plasma concentrations are available, methyltestosterone appears to be the one most likely to impact testosterone immunoassay measurements in males. Norethindrone and nandrolone could produce clinically significant impact on testosterone measurement in women, as may androstenedione in patients with 21-hydroxylase deficiency (Figure 6A, Table 5).

All but one compound (testosterone propionate) that had cross-reactivity of $0.05 \%$ or greater on the Roche assay had 2D similarities to testosterone of 0.8 or greater (Figure 6B). Only 20 of 59 compounds that were noncross-reactive on the Roche testosterone immunoassay had $2 \mathrm{D}$ similarity of 0.8 or higher to testosterone.

\section{Discussion}

Immunoassays are commonly used clinically for measurement of steroid hormone serum/plasma concentrations. In many situations, immunoassays produce results comparable to the more specific chromatography/mass spectrometry-based methods. However, a growing number of studies have documented differences between immunoassays and mass spectrometry methods (especially LC/ MS/MS) [6,7,58-63]. Some differences can be attributed to lower limit of quantitation issues with immunoassays, especially for analytes that may be very low in concentration in some populations (e.g., testosterone in females or estradiol in males). Cross-reactivity to endogenous or exogenous compounds other than the target steroid hormone of the assay may also contribute to differences between immunoassay and LC/MS/MS [4,7,34,60,61]. In this study, we focused on cross-reactivity of Roche Elecsys immunoassays for five steroid hormones (cortisol, DHEA sulfate, estradiol, progesterone, and testosterone).

Previous studies have demonstrated significant crossreactivity of marketed cortisol immunoassays [13,61]. Our studies suggest that false positive cortisol measurements are most likely on the Roche assay during treatment with prednisolone or 6-methylprednisolone, in 21-hydroxylase deficiency due to elevated 21-deoxycortisol, or following metyrapone challenge due to 11-deoxycortisol. This is in accord with package insert data [19]. A study comparing cortisol measurement by immunoassay on the Siemens ADVIA Centaur XP analyzer versus LC/MS/MS demonstrated substantial positive bias of the immunoassay following metyrapone challenge, attributable to interference on the cortisol immunoassay from 11-deoxycortisol [61].

To our knowledge, other than package insert data [31], there is no published data on specificity of DHEA sulfate immunoassays. Our data suggests that crossreactivity is likely not a major issue with the Roche Elecsys assay. In only two scenarios was cross-reactivity predicted to produce false positive DHEA sulfate values 
that would fall within the reference range: pregnenolone sulfate in pregnancy and 17-hydroxyprogesterone in 21-hydroxylase deficiency. In each of these cases, the contribution is likely minor even at maximally predicted interference levels.

A number of studies have compared immunoassay versus mass spectrometry for measurement of plasma/serum estradiol. Estradiol immunoassays often do not perform well relative to LC/MS/MS in measuring the lower end of estradiol concentrations found in males, a limitation likely related primarily to differing lower limits of quantitation between the methods $[59,62,64,65]$. There have been few reports of interferences with estradiol immunoassays. Negative interference by estriol has been reported in a study of the Abbott AxSYM estradiol immunoassay [66]. No significant interference by estrone or estriol was noted in a study of the Abbott Architect estradiol assay [64]. Our cross-reactivity studies suggest that clinically significant cross-reactivity with the Roche Elecsys Estradiol II is unlikely, similar to package insert data [37].

Compared to assays for estradiol and testosterone, there has been relatively little comparative study of progesterone immunoassays with mass spectrometry-based methods. A comparison of 12 progesterone immunoassays with gas chromatography/mass spectrometry (GC/MS) demonstrated high variability in specificity and sensitivity of the immunoassays compared to GC/MS [58]. In our study of the Roche Elecsys Progesterone II immunoassay, the most significant apparent progesterone concentrations were estimated to occur with 17-hydroxyprogesterone in patients with 21-hydroxylase deficiency and for 11deoxycortisol following metyrapone challenge. Medroxyprogesterone and exemestane each may produce apparent progesterone of approximately $0.5 \mathrm{ng} / \mathrm{mL}$. 5 $\beta$-Dihydroprogesterone and allopregnanolone both may produce apparent progesterone concentrations in the range of $0.2 \mathrm{ng} / \mathrm{mL}$. However, with the exception of 17-hydroxyprogesterone in patients with 21-hydroxylase deficiency, none of the other interferences likely produce high enough interference to cause diagnostic issues in women, where progesterone concentrations typically exceed $1 \mathrm{ng} /$ $\mathrm{mL}$. There is the possibility that these interferences could cause significant interference in progesterone measurements in males, although progesterone is typically infrequently measured in males. Doping with exemestane and other aromatase inhibitors has been reported in competitive athletes and others abusing anabolic steroids, primarily as a means to counteract gynecomastia and side effects related to aromatization of anabolic steroids by aromatase [57]. Our results raise the possibility that surreptitious use of aromatase inhibitors could interfere with some steroid hormone measurements by immunoassays.

Anabolic steroids were well-represented among compounds cross-reacting with the Roche Elecsys Testosterone
II immunoassay with six of these compounds (boldenone, 19-norclostebol, dianabol, methyltestosterone, normethandrolone, and 11ß-hydroxytestosterone) producing crossreactivity of $5 \%$ or greater. Norethindrone, a progestogen commonly found in oral contraceptives, also produced strong cross-reactivity. Methyltestosterone, nandrolone, and norethindrone all appear capable of causing clinically significant false positives on the Roche testosterone assay, especially in females. However, interpretation of the clinical significance of the strong cross-reactivity of boldenone, 19-norclostebol, dianabol, normethandrolone, and $11 \beta$ hydroxytestosterone on the testosterone assay is hampered by lack of human pharmacokinetic data. We were unable to locate reliable serum/plasma concentrations for these compounds in humans. There is animal data for some of these compounds [51], mainly due to interest in detecting doping in animal sports such as horse racing, but it is difficult to know how well these data extrapolate to humans.

The results of this study raise interesting questions about the structural differences of diagnostic antibodies used for clinical measurement of steroid hormones. There have been a number of studies looking at the threedimensional structure of antibodies that bind steroid hormones. A crystallographic study of two different estradiol antibodies revealed that antibodies with equally high specificity for estradiol relative to other steroids could, nonetheless, have markedly different amino acid sequence, ligand binding pockets, and ligand orientations [67]. Three studies of anti-testosterone antibodies demonstrated how directed mutagenesis could improve antibody specificity [68-70]. For steroid hormones, it would be of interest to compare and contrast the structure of antibodies used in different marketed immunoassays.

Our results using 2D-similarity to predict steroid hormone cross-reactivity show comparable findings to our previous studies predicting cross-reactivity of drug of abuse and therapeutic drug monitoring assays [14-17]. All compounds with strong cross-reactivity and most with weak cross-reactivity had 2D similarity values of 0.8 or higher to the target steroid molecule of the assay. Although there is some overlap in 2D similarity scores between compounds with strong or weak cross-reactivity and those with no cross-reactivity, use of a $2 \mathrm{D}$ similarity cutoff such as 0.8 would help identify compounds with high likelihood of showing strong cross-reactivity. Conversely, compounds with low $2 \mathrm{D}$ similarity (e.g., less than 0.6) are unlikely to show strong or even weak cross-reactivity. 2D Similarity calculations can thus be used to prioritize compounds for future immunoassay cross-reactivity studies for steroid hormones. This includes novel anabolic steroids used for doping or other as yet uncharacterized compounds, along with metabolites. There are some compounds with high similarity to the target 
molecule of the immunoassay which nonetheless have no cross-reactivity. An example is tetrahydrocortisone for the Roche Elecsys Cortisol immunoassay. It may be necessary to use three-dimensional methods such as pharmacophores or docking to understand why such compounds with strong similarity do not cross-react $[17,53,71]$.

\section{Conclusions}

Clinically significant cross-reactivity on steroid hormone immunoassays generally occurs with structurally similar drugs (e.g., prednisolone and cortisol immunoassays; methyltestosterone and testosterone immunoassays) or with endogenous compounds such as 21-deoxycortisol that can accumulate to very high concentrations in certain disease conditions. Compounds producing cross-reactivity in steroid hormone immunoassays generally have a high degree of structural similarity to the target hormone. Relative simple 2D similarity calculations can help triage compounds for future testing of immunoassay cross-reactivity.

\section{Additional file}

Additional file 1: Cross-reactivity, similarity, vendor source, and assay details. Spreadsheet with complete data on cross-reactivity, 2D-similarity calculations, vendor sources for compounds tested for cross-reactivity, and immunoassay details.

\section{Abbreviations}

DHEA: Dehydroepiandrosterone; ELISA: Enzyme-linked immunosorbent assay; GC/MS: Gas chromatography/mass spectrometry; HPLC: High-performance liquid chromatography; MS: Mass spectrometry; 2D: Two-dimensional.

\section{Competing interests}

All authors (MDK, DD, CSM, JM, JLB, SE) declare that they have no competing interests.

\section{Authors' contributions}

MDK, JLB, and SE were involved in the study concept and design, analysis and interpretation of the data, drafting and revisions of the manuscript. DD, CSM, and JM performed the cross-reactivity studies. All authors have read and approved the final manuscript.

\section{Acknowledgements}

MDK thanks the Department of Pathology (Drs. Barry De Young and Nitin Karandikar, past and current Department Executive Officers, respectively) for providing research funding. SE kindly acknowledges Accelrys, Inc. for providing Discovery Studio.

\section{Author details}

1 Department of Pathology, University of lowa Hospitals and Clinics, 200 Hawkins Drive, C-671 GH, lowa, IA 52242, USA. ²Department of Pathology, University of Michigan, Ann Arbor, MI 48109, USA. ${ }^{3}$ Collaborations in Chemistry, Fuquay-Varina, NC 27526, USA.

Received: 25 November 2013 Accepted: 11 July 2014 Published: 14 July 2014

\section{References}

1. Holder G: Measurement of glucocorticoids in biological fluids. Methods Mol Biol 2006, 324:141-157.

2. Wheeler MJ: Measurement of androgens. Methods Mol Biol 2006, 324:197-211.
3. Kricka LJ: Principles of immunochemical techniques. In Tietz textbook of clinical chemistry and molecular diagnostics. 4th edition. Edited by Burtis CA, Ashwood ER, Bruns DE. St. Louis, MO: Elsevier Saunders; 2006:219-243.

4. Kulle AE, Welzel M, Holterhus PM, Riepe FG: Principles and clinical applications of liquid chromatography - tandem mass spectrometry for the determination of adrenal and gonadal steroid hormones. J Endocrinol Invest 2011, 34:702-708.

5. Rauh M: Steroid measurement with LC-MS/MS. Application examples in pediatrics. J Steroid Biochem Mol Biol 2010, 121:520-527.

6. Shackleton C: Clinical steroid mass spectrometry: a 45-year history culminating in HPLC-MS/MS becoming an essential tool for patient diagnosis. J Steroid Biochem Mol Biol 2010, 121:481-490.

7. Soldin SJ, Soldin OP: Steroid hormone analysis by tandem mass spectrometry. Clin Chem 2009, 55:1061-1066.

8. Klee GG: Interferences in hormone immunoassays. Clin Lab Med 2004, 24:1-18.

9. Kricka LJ: Interferences in immunoassays - still a threat. Clin Chem 2000, 46:1037-1038.

10. Middle JG: Dehydroepiandrostenedione sulphate interferes in many direct immunoassays for testosterone. Ann Clin Biochem 2007, 44:173-177.

11. Warner MH, Kane JW, Atkin SL, Kilpatrick ES: Dehydroepiandrosterone sulphate interferes with the Abbott Architect direct immunoassay for testosterone. Ann Clin Biochem 2006, 43:196-199.

12. Tejada F, Cremades A, Monserrat F, Penafiel R: Interference of the antihormone RU486 in the determination of testosterone and estradiol by enzyme-immunoassay. Clin Chim Acta 1998, 275:63-69.

13. Roberts RF, Roberts WL: Performance characteristics of five automated serum cortisol immunoassays. Clin Biochem 2004, 37:489-493.

14. Krasowski MD, Pizon AF, Siam MG, Giannoutsos S, lyer M, Ekins S: Using molecular similarity to highlight the challenges of routine immunoassaybased drug of abuse/toxicology screening in emergency medicine. BMC Emerg Med 2009, 9:5.

15. Krasowski MD, Siam MG, lyer M, Ekins S: Molecular similarity methods for predicting cross-reactivity with therapeutic drug monitoring immunoassays. Ther Drug Monit 2009, 31:337-344.

16. Krasowski MD, Siam MG, lyer M, Pizon AF, Giannoutsos S, Ekins S: Chemoinformatic methods for predicting interference in drug of abuse/ toxicology immunoassays. Clin Chem 2009, 55:1203-1213.

17. Petrie M, Lynch KL, Ekins S, Chang JS, Goetz RJ, Wu AH, Krasowski MD: Cross-reactivity studies and predictive modeling of "Bath Salts" and other amphetamine-type stimulants with amphetamine screening immunoassays. Clin Toxicol (Phila) 2013, 51:83-91.

18. Powers DM, Boyd JC, Glick MR: Interference testing in clinical chemistry (EP7-A). NCCLS: Villanova, PA; 1986.

19. Cortisol package insert for Elecsys 1010, Elecsys 2010, Modular Analytics E170, cobas e 411, and cobas e 601. 2008-04, V2 English. Indianapolis, IN, USA: Roche Diagnostics.

20. Al-Habet SM, Rogers HJ: Methylprednisolone pharmacokinetics after intravenous and oral administration. Br J Clin Pharmacol 1989, 27:285-290.

21. McBride JH, Rodgerson DO, Park SS, Reyes AF: Rapid liquid-chromatographic method for simultaneous determination of plasma prednisone, prednisolone, and cortisol in pediatric renal-transplant recipients. Clin Chem 1991, 37:643-646.

22. Tonetto-Fernandes V, Lemos-Marini SH, Kuperman H, Ribeiro-Neto LM, Verreschi IT, Kater CE: Serum 21-Deoxycortisol, 17-Hydroxyprogesterone, and 11-deoxycortisol in classic congenital adrenal hyperplasia: clinical and hormonal correlations and identification of patients with 11 beta-hydroxylase deficiency among a large group with alleged 21-hydroxylase deficiency. J Clin Endocrinol Metab 2006, 91:2179-2184.

23. Ribot M, Polito A, Grassin-Delyle S, Annane D, Alvarez JC: Human plasma quantification of fludrocortisone using liquid chromatography coupled with atmospheric pressure chemical ionization mass spectrometry after low-dosage administration. Clin Chim Acta 2013, 420:109-113.

24. Mayo Medical Laboratories (Rochester, MN). [http://www. mayomedicallaboratories.com/]

25. Berneis K, Staub JJ, Gessler A, Meier C, Girard J, Muller B: Combined stimulation of adrenocorticotropin and compound-S by single dose metyrapone test as an outpatient procedure to assess hypothalamicpituitary-adrenal function. J Clin Endocrinol Metab 2002, 87:5470-5475.

26. Abosehmah-Albidy AZ, York P, Wong V, Losowsky MS, Chrystyn $\mathrm{H}$ : Improved bioavailability and clinical response in patients with chronic 
liver disease following the administration of a spironolactone: beta-cyclodextrin complex. Br J Clin Pharmacol 1997, 44:35-39.

27. Jankowski A, Skorek-Jankowska A, Lamparczyk H: Simultaneous determination of spironolactone and its metabolites in human plasma. J Pharm Biomed Anal 1996, 14:1359-1365.

28. Sandall JM, Millership JS, Collier PS, McElnay JC: Development and validation of an HPLC method for the determination of spironolactone and its metabolites in paediatric plasma samples. J Chromatogr B Analyt Technol Biomed Life Sci 2006, 839:36-44.

29. Lonning PE, Geisler J, Johannessen DC, Gschwind HP, Waldmeier F Schneider W, Galli B, Winkler T, Blum W, Kriemler HP, Miller WR, Faigle JW: Pharmacokinetics and metabolism of formestane in breast cancer patients. J Steroid Biochem Mol Biol 2001, 77:39-47.

30. von Schnakenburg K, Bidlingmaier F, Knorr D: 17-hydroxyprogesterone, androstenedione, and testosterone in normal children and in prepubertal patients with congenital adrenal hyperplasia. Eur J Pediatr 1980, 133:259-267.

31. DHEA sulfate package insert for Elecsys 1010, Elecsys 2010, Modular Analytics E170, cobas e 411, and cobas e 601. 2009-03, V13 English. Indianapolis, IN, USA: Roche Diagnostics.

32. Tagawa N, Tamanaka J, Fujinami A, Kobayashi Y, Takano T, Fukata S, Kuma K, Tada H, Amino N: Serum dehydroepiandrosterone, dehydroepiandrosterone sulfate, and pregnenolone sulfate concentrations in patients with hyperthyroidism and hypothyroidism. Clin Chem 2000, 46:523-528.

33. Klak J, Hill M, Parizek A, Havlikova H, Bicikova M, Hampl R, Fait T, Sulcova J, Pouzar V, Kancheva R, Starka L: Pregnanolone isomers, pregnenolone and their polar conjugates around parturition. Physiol Res 2003, 52:211-221.

34. Kushnir MM, Rockwood AL, Roberts WL, Pattison EG, Owen WE, Bunker AM, Meikle AW: Development and performance evaluation of a tandem mass spectrometry assay for 4 adrenal steroids. Clin Chem 2006, 52:1559-1567.

35. Hill M, Lukac D, Lapcik O, Sulcova J, Hampl R, Pouzar V, Starka L: Age relationships and sex differences in serum levels of pregnenolone and 17-hydroxypregnenolone in healthy subjects. Clin Chem Lab Med 1999, 37:439-447.

36. Lee MM, Rajagopalan L, Berg GJ, Moshang T Jr: Serum adrenal steroid concentrations in premature infants. J Clin Endocrinol Metab 1989 69:1133-1136.

37. Estradiol II package insert for Elecsys 1010, Elecsys 2010, Modular Analytics E170, cobas e 411, and cobas e 601. 2009-05, V15 English. Indianapolis, IN, USA: Roche Diagnostics.

38. Abrams LS, Skee DM, Natarajan J, Wong FA, Anderson GD: Pharmacokinetics of a contraceptive patch (Evra/Ortho Evra) containing norelgestromin and ethinyloestradiol at four application sites. $\mathrm{Br} J \mathrm{Clin}$ Pharmacol 2002, 53:141-146.

39. Barditch-Crovo P, Trapnell CB, Ette E, Zacur HA, Coresh J, Rocco LE, Hendrix $C W$, Flexner $C$ : The effects of rifampin and rifabutin on the pharmacokinetics and pharmacodynamics of a combination oral contraceptive. Clin Pharmacol Ther 1999, 65:428-438.

40. Hendrix CW, Jackson KA, Whitmore E, Guidos A, Kretzer R, Liss CM, Shah LP, Khoo KC, McLane J, Trapnell CB: The effect of isotretinoin on the pharmacokinetics and pharmacodynamics of ethinyl estradiol and norethindrone. Clin Pharmacol Ther 2004, 75:464-475.

41. Trapnell CB, Donahue SR, Collins JM, Flockhart DA, Thacker D, Abernethy DR: Thalidomide does not alter the pharmacokinetics of ethinyl estradiol and norethindrone. Clin Pharmacol Ther 1998, 64:597-602

42. Troisi R, Potischman N, Roberts JM, Harger G, Markovic N, Cole B, Lykins D, Siiteri $\mathrm{P}$, Hoover RN: Correlation of serum hormone concentrations in maternal and umbilical cord samples. Cancer Epidemiol Biomarkers Prev 2003, 12:452-456.

43. Wright JV, Schliesman B, Robinson L: Comparative measurements of serum estriol, estradiol, and estrone in non-pregnant, premenopausal women; a preliminary investigation. Altern Med Rev 1999, 4:266-270.

44. Progesterone Il package insert for Elecsys 1010, Elecsys 2010, Modular Analytics E170, cobas e 411, and cobas e 601. 2009-05, V12 English. Indianapolis, IN USA: Roche Diagnostics.

45. Baghai TC, di Michele F, Schule C, Eser D, Zwanzger P, Pasini A, Romeo E, Rupprecht R: Plasma concentrations of neuroactive steroids before and after electroconvulsive therapy in major depression. Neuropsychopharmacology 2005, 30:1181-1186.

46. Ohtsu T, Fujii H, Wakita H, Igarashi T, Itoh K, Imoto S, Kohagura M, Sasaki Y: Pharmacokinetic study of low- versus high-dose medroxyprogesterone acetate (MPA) in women. Cancer Chemother Pharmacol 1998, 42:1-8.
47. Bagchus WM, Smeets JM, Verheul HA, De Jager-Van Der Veen SM, Port A, Geurts TB: Pharmacokinetic evaluation of three different intramuscular doses of nandrolone decanoate: analysis of serum and urine samples in healthy men. J Clin Endocrinol Metab 2005, 90:2624-2630.

48. Evans TR, Di Salle E, Ornati G, Lassus M, Benedetti MS, Pianezzola E, Coombes RC: Phase I and endocrine study of exemestane (FCE 24304), a new aromatase inhibitor, in postmenopausal women. Cancer Res 1992 52:5933-5939.

49. Testosterone Il package insert for Elecsys 2010, Modular Analytics E170, cobas e 411, and cobas e 601. 2010-05, V1 English. Indianapolis, IN, USA: Roche Diagnostics.

50. Shinohara $Y$, Baba S: Stable isotope methodology in the pharmacokinetic studies of androgenic steroids in humans. Steroids 1990, 55:170-176.

51. Soma LR, Uboh CE, Guan F, McDonnell S, Pack J: Pharmacokinetics of boldenone and stanozolol and the results of quantification of anabolic and androgenic steroids in race horses and nonrace horses. J Vet Pharmacol Ther 2007, 30:101-108

52. Bender A, Glen RC: Molecular similarity: a key technique in molecular informatics. Org Biomol Chem 2004, 2:3204-3218.

53. Ekins S, Mestres J, Testa B: In silico pharmacology for drug discovery: applications to targets and beyond. Br J Pharmacol 2007, 152:21-37.

54. Reddy AS, Pati SP, Kumar PP, Pradeep HN, Sastry GN: Virtual screening in drug discovery - a computational perspective. Curr Protein Pept Sci 2007 8:329-351.

55. Ayotte C: Detecting the administration of endogenous anabolic androgenic steroids. Handb Exp Pharmacol, 2010:77-98.

56. Calvo D, Tort N, Salvador JP, Marco MP, Centi F, Marco S: Preliminary study for simultaneous detection and quantification of androgenic anabolic steroids using ELISA and pattern recognition techniques. Analyst 2011, 136:4045-4052.

57. Lippi G, Franchini M, Banfi G: Biochemistry and physiology of anabolic androgenic steroids doping. Mini Rev Med Chem 2011, 11:362-373.

58. Boudou P, Taieb J, Mathian B, Badonnel Y, Lacroix I, Mathieu E, Millot F, Queyrel N, Somma-Delpero C, Patricot MC: Comparison of progesterone concentration determination by 12 non-isotopic immunoassays and gas chromatography/mass spectrometry in 99 human serum samples. J Steroid Biochem Mol Biol 2001, 78:97-104.

59. Huhtaniemi IT, Tajar A, Lee DM, O'Neill TW, Finn JD, Bartfai G, Boonen S, Casanueva FF, Giwercman A, Han TS, Kula K, Labrie F, Lean ME, Pendleton N, Punab M, Silman AJ, Vanderschueren D, Forti G, Wu FC: Comparison of serum testosterone and estradiol measurements in 3174 European men using platform immunoassay and mass spectrometry; relevance for the diagnostics in aging men. Eur J Endocrinol 2012, 166:983-991.

60. Moal V, Mathieu E, Reynier P, Malthiery Y, Gallois Y: Low serum testosterone assayed by liquid chromatography-tandem mass spectrometry. Comparison with five immunoassay techniques. Clin Chim Acta 2007, 386:12-19.

61. Monaghan PJ, Owen L, Trainer PJ, Brabant G, Keevil BG, Darby D: Comparison of serum cortisol measurement by immunoassay and liquid chromatography-tandem mass spectrometry in patients receiving the 11 beta-hydroxylase inhibitor metyrapone. Ann Clin Biochem 2011, 48:441-446.

62. Ohlsson C, Nilsson ME, Tivesten A, Ryberg H, Mellstrom D, Karlsson MK, Ljunggren O, Labrie F, Orwoll ES, Lee DM, Pye SR, O'Neill TW, Finn JD, Adams JE, Ward KA, Boonen S, Bartfai G, Casanueva FF, Forti G, Giwercman A, Han TS, Huhtaniemi IT, Kula K, Lean ME, Pendleton N, Punab M, Vanderschueren D, Wu FC, Vandenput L: Comparisons of immunoassay and mass spectrometry measurements of serum estradiol levels and their influence on clinical association studies in men. J Clin Endocrinol Metab 2013, 98:E1097-E1102.

63. Stanczyk FZ, Clarke NJ: Advantages and challenges of mass spectrometry assays for steroid hormones. J Steroid Biochem Mol Biol 2010, 121:491-495.

64. Sluss PM, Hayes FJ, Adams JM, Barnes W, Williams G, Frost S, Ramp J, Pacenti D, Lehotay DC, George S, Ramsay C, Doss RC, Crowley WF, Jr.: Mass spectrometric and physiological validation of a sensitive, automated, direct immunoassay for serum estradiol using the Architect. Clin Chim Acta 2008, 388:99-105

65. Yang DT, Owen WE, Ramsay CS, Xie H, Roberts WL: Performance characteristics of eight estradiol immunoassays. Am J Clin Pathol 2004, 122:332-337.

66. Cao Z, Swift TA, West CA, Rosano TG, Rej R: Immunoassay of estradiol: unanticipated suppression by unconjugated estriol. Clin Chem 2004, 50:160-165.

67. Monnet C, Bettsworth F, Stura EA, Le Du MH, Menez R, Derrien L, Zinn-Justin S, Gilquin B, Sibai G, Battail-Poirot N, Jolivet M, Menez A, Arnaud M, Ducancel F, 
Charbonnier JB: Highly specific anti-estradiol antibodies: structural characterisation and binding diversity. J Mol Biol 2002, 315:699-712.

68. Hemminki A, Niemi S, Hoffren AM, Hakalahti L, Soderlund H, Takkinen K: Specificity improvement of a recombinant anti-testosterone Fab fragment by CDRIII mutagenesis and phage display selection. Protein Eng 1998, 11:311-319.

69. Valjakka J, Hemminki A, Niemi S, Soderlund H, Takkinen K, Rouvinen J: Crystal structure of an in vitro affinity- and specificity-matured anti-testosterone Fab in complex with testosterone. Improved affinity results from small structural changes within the variable domains. J Biol Chem 2002, 277:44021-44027.

70. Valjakka J, Takkinenz K, Teerinen T, Soderlund H, Rouvinen J: Structural insights into steroid hormone binding: the crystal structure of a recombinant anti-testosterone Fab fragment in free and testosterone-bound forms. J Biol Chem 2002, 277:4183-4190.

71. Kortagere $S$, Krasowski MD, Ekins S: The importance of discerning shape in molecular pharmacology. Trends Pharmacol Sci 2009, 30:138-147.

doi:10.1186/1472-6890-14-33

Cite this article as: Krasowski et al:: Cross-reactivity of steroid hormone immunoassays: clinical significance and two-dimensional molecular similarity prediction. BMC Clinical Pathology 2014 14:33.

\section{Submit your next manuscript to BioMed Central and take full advantage of:}

- Convenient online submission

- Thorough peer review

- No space constraints or color figure charges

- Immediate publication on acceptance

- Inclusion in PubMed, CAS, Scopus and Google Scholar

- Research which is freely available for redistribution 